\title{
RACISMO NO CURRÍCULO DE HISTÓRIA: A VISÃO DOS DISCENTES DO ENSINO MÉDIO DE SÃO PAULO
}

\section{RACISM IN THE HISTORY CURRICULUM: THE VIEW OF HIGH SCHOOL STUDENTS IN SÃO PAULO}

\section{RESUMO}

Após dez anos da promulgação do Estatuto da Igualdade Racial e dezessete da aprovação da Lei $n .^{\circ}$ 10.639/o3, observa-se que tanto na rede pública como na rede privada de ensino, ainda persistem as práticas racistas. Sendo que o currículo de história deve ser analisado e questionado com o objetivo de entender se superou a historiografia eurocêntrica, que apresenta a população negra como inferior. A partir dessa problemática, a presente pesquisa tem como objeto a visão dos discentes do Ensino Médio sobre a aplicação da referida Lei no currículo de História. O objetivo principal é explicitar as percepções desses(as) estudantes sobre o racismo no Brasil e especialmente no currículo escolar. Para tanto, realizou-se pesquisa bibliográfica tendo como principais teóricos: MEMMI, 1977, FREIRE, 2005 e SILVA, 1999, combinada a entrevistas. Optou-se por entrevistar seis discentes da terceira série do ensino médio, que se autodeclarassem negros(as), sendo três da rede pública e três da rede privada. Os resultados apontam que, na escola pública, houve poucas mudanças com relação à abordagem do negro na história. Na escola particular, o conteúdo da referida Lei é abordada com maior frequência, mas o currículo não é propício para assunção da identidade dos estudantes negros(as) presentes nessa rede.

Palavras-chave: Currículo. História. Racismo.

\section{ABSTRACT}

Ten years after the enactment of the Racial Equality Statute and seventeen after the approval of Law No. 10,639 / 03, it is observed that both in the public and private schools, racist practices still persist. Since the history curriculum must be analyzed and questioned in order to understand whether it has overcome the eurocentric historiography, which presents the black population as inferior. Based on this problem, the present research has as its object the view of high school students on the application of said Law in the 
History curriculum. The main objective is to explain the perceptions of these students about racism in Brazil and especially in the school curriculum. For this, bibliographic research was carried out with the main theorists: MEMMI, 1977, FREIRE, 2005 and SILVA, 1999, combined with interviews. It was decided to interview six students from the third grade of high school, who declared themselves black, three of them from public schools and three from private schools. The results show that, in the public school, there were few changes regarding the approach of blacks in history. In the private school, the content of that Law is addressed more frequently, but the curriculum is not conducive to black students present in this network assuming their identity.

Keywords: Curriculum. Story. Racism. 


\section{INTRODUÇÃO}

No Brasil, o tráfico de seres humanos escravizados se inicia no primeiro século de colonização portuguesa, na década de 1530 e caracteriza-se pela crueldade com que os africanos foram tratados, tanto por ocasião do rapto em África, quanto durante a travessia no Atlântico.

O tráfico de africanos foi extremamente lucrativo para o comércio colonial, uma vez que permitia a acumulação primitiva de capital na metrópole e, por isso, dentre outros motivos, a escravização dos africanos foi preferida à escravização ameríndia, pois a segunda beneficiava muito mais o comércio interno (NOVAES, 1979).

A formação social do país foi escravista desde o século XVI, sendo marcada pelo surgimento de propriedades rurais voltadas para a produção com base no trabalho escravizado, a princípio dos autóctones, depois, de negros e autóctones e, no final, praticamente, só de negros (SAES, 1985). Contudo, a história do Brasil, não destaca a relevância do povo negro na formação da sociedade brasileira e, apresenta uma visão eurocêntrica que percebe a história a partir da visão dos colonizadores.

Por isso, é necessário que a História do Brasil seja contada com a inclusão das vozes silenciadas dos povos marginalizados, apontando no currículo escolar que o tráfico de africanos não se deu ao acaso, mas a partir de interesses políticos e, principalmente, econômicos.

É preciso ressaltar que os negros escravizados não eram "boçais" e não foram capturados ao acaso. Foram capturados de acordo com o conhecimento que detinham: mineração, tecnologia da metalurgia, lida no campo, trabalho com o couro, confecção de tecidos, entre outros conhecimentos tecnológicos que interessavam à colônia portuguesa.

Inclusive, algumas indústrias surgidas durante o Império empregavam trabalhadores escravizados, como a primeira fábrica de fiação e tecidos de algodão no Pernambuco, em 1822 e a metalúrgica de Ponta da Areia, no Rio de Janeiro, criada por 
Mauá, em 1845, que "[...] chegou a contar com mil trabalhadores e foi palco da primeira greve de escravos na indústria brasileira" (SAES, 1985, p. 226).

A História do Brasil precisa começar a ser contada a partir da visão de mundo dos "vencidos", desconstruindo o estereótipo de que o negro é preguiçoso e combatendo ditados e expressões discriminatórias como: "amanhã é dia de branco", "buraco negro", "caixa preta", "serviço de preto", "um negro parado é suspeito, um negro correndo é ladrão" "a coisa tá preta" e tantos outros que "denigrem" o ser negro no Brasil.

A propósito, de acordo com Ferreira Aurélio (1993, p. 165), denegrir significa "enegrecer, manchar, infamar" e, para o Dicionário Online de Português (2014), "obscurecer ou obscurecer-se; fazer ficar mais negro ou escuro; reduzir a transparência de; manchar-se; figurado". Sendo assim, a nossa língua também colabora para a visão de que tudo que é preto/negro é sinônimo de coisa ruim, significa a derrota, a morte, o imundo, o cão, o demo, o sujo, o encardido, o sombrio, o lúgubre (FERREIRA, 1993; GUIMARÃES, 2008) e tantas outras denominações de conotação sociológica negativa, que ainda hoje derivam do ser humano negro, confirmando a simbologia de cores das formações sociais ocidentais, em que a cor preta representa a corrupção, o pecado e o demônio. E, por influência das igrejas cristãs, ainda hoje, o preto é a representação do diabo, de Exu, sendo comum o diabo ser representado como um homem preto com chifres e rabo.

Partindo desse contexto, o presente estudo tem como objeto a visão dos discentes do Ensino Médio sobre a aplicação da Lei n. ${ }^{0}$ 10.639/o3 no currículo de História, bem como das práticas dos professores dessa disciplina no mesmo curso.

Para tanto, tem-se que a Lei n. ${ }^{0} 10.639 / 03$ foi promulgada em 2003 atendendo antigas reivindicações da população negra, essa Lei estabelece as diretrizes e bases da educação nacional, incluindo no currículo oficial da Rede de Ensino a obrigatoriedade da temática "História e Cultura Afro-Brasileira", determinando que o conteúdo programático incluirá o estudo da História da África e dos Africanos, a luta dos negros no Brasil, a cultura negra brasileira e o negro na formação da sociedade nacional, resgatando a 
contribuição do povo negro nas áreas social, econômica e política pertinentes à História do Brasil (BRASIL, 2003).

\section{RACISMO}

Em 2002, a cantora negra Elza Soares gravou a música "A carne”, de autoria de Marcelo Yuka, Ulisses Cappelletti e Seu Jorge. A canção é uma interessante definição do que é racismo, preconceito racial e discriminação:

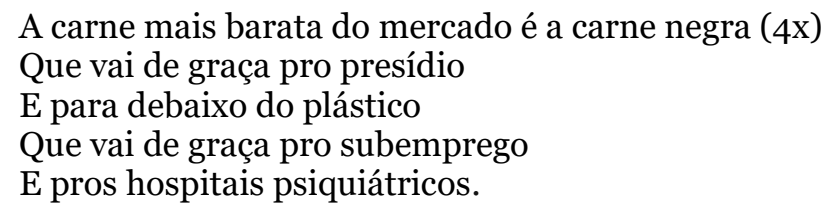

A primeira frase "a carne mais barata do mercado é a carne negra" explicita o racismo como doutrina da superioridade de determinados grupos étnicos sobre outros. Para Lopes (2004), o conceito de superioridade racial carece de base científica, uma vez que as diferenças biológicas entre os diversos povos são variedades de uma mesma espécie. Entretanto, no Brasil, observa-se uma clara distinção entre o tratamento dispensado à população branca e à não-branca. "A carne negra vai de graça pro presídio e para debaixo do plástico". O Mapa da Violência de 2014 confirma esta frase, pois “[...] entre os brancos, o número de vítimas (homicídios entre 2002 e 2012) diminuiu de 19.846 para 14.928, o que representa uma queda de 24,8\%. Entre os negros, as vítimas aumentaram de 29.656 para 41.127, crescimento 38,7\%" (WAISELFISZ, 2014, p. 150), ou seja, no período pesquisado, o número de negros “debaixo do plástico" é quase três vezes maior do que de brancos.

Dados fornecidos pelo Levantamento Nacional de Informações Penitenciárias (Infopen) informam que "[...] a população penitenciária brasileira chegou a 622.202 pessoas em dezembro de 2014. O perfil socioeconômico dos detentos mostra que 55\% têm entre 18 e 29 anos de idade, 61,6\% são negros e 75,08\% têm até o ensino fundamental 
completo" (BRASIL, 2016, p.1). E é a "Carne negra que vai de graça pro subemprego e pros hospitais psiquiátricos": dados do IBGE publicados no Portal Brasil revelam "[...] que os trabalhadores de cor preta ou parda ganhavam, em média, em 2014, 58,0\% do rendimento recebido pelos trabalhadores de cor branca” (BRASIL, 2015, p.1) e, de acordo com pesquisa realizada por Diniz (2013), o perfil dos internados psiquiátricos e sob custódia são: homens negros (44\% contra 38\% de brancos), pobres, de baixa escolaridade e com inserção periférica no mercado de trabalho.

Esses dados exigem uma reflexão de como o preconceito que, para Cashmore (2000, p. 438), “[...] pode ser definido como o conjunto de crenças e valores aprendidos, que levam um indivíduo ou um grupo a nutrir opiniões a favor ou contra os membros de determinados grupos, antes de efetiva experiência com estes"; transforma-se em discriminação racial, que "[...] é uma ação ou comportamento adotados de forma a prejudicar alguém, isto é, quando o racista ou o preconceituoso externiza sua atitude, em manifestações ou ação, ocorre a discriminação" (CONE, 2010, p. 8). A "Carne negra" poderia ser vítima de preconceito por conta de uma sociedade ignorante, mas, na verdade, é vítima de discriminação racial e racismo institucional, pois esses(as) senhores(as) com mentes branqueadas e colonizadas apoiam instituições, "[...] que entendem que um determinado grupo racial deve ter preferência em relação a outros grupos em matéria de acesso aos benefícios gerados" (id., ib.).

Memmi (1977) ponderou sobre as relações entre racismo e colonialismo e, apesar de referir-se ao racismo colonial que impregnava os países africanos na década de 1970, seus conceitos se aplicam ao caso brasileiro, em que o racismo é adquirido e exercido desde a infância. Há um esforço constante das classes dominantes para descobrir e evidenciar as diferenças entre os negros e brancos, valorizando-as em favor dos segundos, de modo que a população negra continue sendo "A carne mais barata do mercado".

Contudo, existem conquistas no âmbito legal que devem ser discutidas com a população negra, para que, a partir da tomada de consciência de seus direitos, essa população possa romper com o ciclo de opressão e alienação. Caso contrário, 
possivelmente o processo de revolta irá ampliar-se e chegará o momento da "justa ira” de cobrar toda a dívida histórica.

Referentemente às conquistas legais, tem-se no art. $5 .^{\circ}$, inciso XLII, da Constituição Federal de 1988, que determina: “[...] a prática do racismo constitui crime inafiançável e imprescritível, sujeito de reclusão nos termos da lei”. A Lei n. ${ }^{0}$ 9.459/97 incluiu, no artigo $1 .^{\circ}$, “[...] a punição pelos crimes resultantes de discriminação e preconceito de raça, cor, etnia, religião ou procedência nacional”. No artigo 20 da mesma norma, determinou-se que praticar, induzir ou incitar a discriminação ou preconceito de raça, cor, etnia, religião ou procedência nacional é crime com pena de reclusão de um a três anos e multa (BRASIL, 1997).

No ano de 2010, houve outra importante conquista: foi sancionado o Estatuto da Igualdade Racial, com base na Lei n. ${ }^{0}$ 12.288, “[... ] destinado a garantir à população negra a efetivação da igualdade de oportunidades, a defesa dos direitos étnicos individuais, coletivos e difusos e o combate à discriminação e às demais formas de intolerância étnica” (BRASIL, 2010). E para que não haja dúvidas, o art. 1. ${ }^{\circ}$, do Estatuto determina:

\section{[...]}

I - discriminação racial ou étnico-racial: toda distinção, exclusão, restrição ou preferência baseada em raça, cor, descendência ou origem nacional ou étnica que tenha por objeto anular ou restringir o reconhecimento, gozo ou exercício, em igualdade de condições, de direitos humanos e liberdades fundamentais nos campos político, econômico, social, cultural ou em qualquer outro campo da vida pública ou privada (BRASIL, 2010).

No capítulo II do mesmo documento, relativamente ao direito à educação, à cultura, ao esporte e ao lazer, consta que “[...] a população negra tem direito a participar de atividades educacionais, culturais, esportivas e de lazer adequadas a seus interesses e condições" (BRASIL, 2010). Além disso, prescreve que é dever do Estado o desenvolvimento de campanhas educativas para que a solidariedade aos membros da população negra faça parte da cultura de toda a sociedade.

Após dez anos da promulgação do Estatuto da Igualdade Racial e dezessete anos da aprovação da Lei n. ${ }^{0}$ 10.639/o3, a presente pesquisa apresenta os relatos de estudantes 
negros tanto da região periférica, como de bairros de classe média da zona leste de São Paulo, buscando explicitar as percepções desses meninos e meninas sobre o racismo no Brasil e especialmente no currículo escolar.

\section{CURRÍCULO}

O currículo, que não se limita a uma série de disciplinas e seus conteúdos, mas trata-se do currículo em sentido amplo, que diz respeito a, praticamente, todo fenômeno educacional e aos seres humanos envolvidos no processo. Para Libânio (2003) o currículo, mais do que os conteúdos escolares inscritos nas disciplinas, é o conjunto dos vários tipos de aprendizagens; valores, comportamentos, atitudes adquiridas nas vivencias cotidianas na comunidade, nos jogos, no recreio e na interação entre professores, estudantes e funcionários.

De acordo com a Resolução $n^{0}$ 4, de 13 de julho de 2010, que define Diretrizes Curriculares Nacionais Gerais para a Educação Básica, o currículo: “Configura-se como o conjunto de valores e práticas que proporcionam a produção, a socialização de significados no espaço social e contribuem intensamente para a construção de identidades socioculturais dos educandos" (BRASIL, MEC, RESOLUÇÃO CNE/CEB 4/2010, p.4).

Em outras palavras, o currículo refere-se às atividades organizadas pela escola, que se desdobram em torno do conhecimento, contribuindo para a construção das identidades dos(as) estudantes, sendo fundamental o papel do educador no processo curricular .

Silva (2010) chama atenção para o currículo que representando um "corpus ideológico" da classe dominante, acaba se entrelaçando ao cotidiano escolar, interferindo no projeto de educação de toda comunidade. Portanto, o currículo não é imparcial e como afirma Apple (1999, p.59) o currículo “nunca é apenas um conjunto neutro de conhecimentos [...]. Ele sempre é parte de uma tradição seletiva, resultado da seleção de alguém, da visão de algum grupo acerca do que seja conhecimento legítimo”, sendo constituído não somente pelo currículo explícito, para além deste, existe também o currículo oculto. 
Em virtude da coexistência dos currículos e da sua não neutralidade ainda é relevante as discussões nos meios acadêmicos e no "chão da escola" para debater tanto o currículo formal, quanto o oculto. Buscando caminhos para o currículo ser mais atraente e congruente com a realidade da comunidade escolar e possivelmente, como defende Silva (2001), enxergando o currículo como fetiche, superando a dicotomia entre as experiências reais e imaginárias, sendo um currículo em que os conhecimentos possam ser elencados pelos(as) sujeitos reinterpretando as divergências, conflitos e controvérsias e reconhecendo as características comuns das formas de conhecimento.

As discussões acerca do currículo possivelmente serão mais profícuas, se as comunidades escolares e acadêmicas tiverem conhecimento sobre as conceituações e teorias do currículo. Atualmente encontram-se vários estudos sobre teorias do currículo, o brasileiro Tadeu da Silva (1999, p.12) é um estudioso do tema e para esse autor, seria mais apropriado renomear os estudos sobre teorias do currículo, como "discursos e perspectivas sobre currículo", uma vez que "uma teoria supostamente descobre um objeto que tem uma existência independente relativamente da teoria. Um discurso em troca, produz seu próprio objeto [...]. Um discurso sobre o currículo, [...] produz uma noção particular de currículo”.

Contudo, o próprio autor adverte que a utilização da palavra "teoria" esta tão difundida que seria difícil abandoná-la. Para efeito desta pesquisa utilizar-se-á a palavra teorias sobre currículo, no sentido de ser uma noção particular de currículo.

Para Silva (1999), o que vai distinguir as teorias a respeito do currículo é a questão do poder. As teorias tradicionais apresentam-se como neutras com foco no ensino, aprendizagem, avaliação, metodologia, didática, organização, planejamento, eficiência e objetivos, estando mais concentrados nas questões técnicas. Em contrapartida, as teorias críticas e pós-críticas negam a suposta neutralidade do currículo, questionando o: "Por que privilegiar um determinado tipo de identidade ou subjetividade e não outro? " $i d$., ib., p.16). Os discursos críticos enfatizam os conceitos de ideologia e privilegiam as categorias: ideologia, reprodução cultural e social, poder, classe social, relações de 
produção, conscientização, emancipação e libertação, currículo oculto e resistência. Por sua vez, as teorias pós-críticas destacam o conceito de discurso em vez do conceito de ideologia, tendo como principais categorias: identidade, alteridade, diferença, subjetividade, significação e discurso, saber-poder, cultura, gênero, raça, etnia, sexualidade e multiculturalismo.

Para Young (2014) as teorias sobre currículo estão mais interessadas no currículo como conhecimento dos poderosos do que o currículo como conhecimento poderoso. Essa abordagem de Young é relevante por permitir uma postura mais ativa com relação aos currículos, que não precisam ser encarados como estáticos e sim como campos de atuação e destaque para diferentes conhecimentos. Podendo ser um espaço de valorização e promoção da identidade etnicorracial, em que disciplinas como de História deve problematizar os critérios que abordam a história da África e Afro-brasileira a partir de periodizações eurocêntricas.

A respeito dessa valorização Santos (2010) propõe: i) apresentar periodizações africanas; ii) que a disciplina de história analise os modos de produção e organização social e política que não sejam pautados nos padrões ocidentais (direita, esquerda, capitalismo, socialismo); iii) que a história possa contribuir para descontruir equívocos em torno do povo africano e afro-brasileiro e finalmente que

E considerando os inúmeros discursos sobre currículo, explicita-se que a presente pesquisa está pautada no conceito freiriano. Segundo Saul (2010, p. 109), “[...] currículo é, na acepção freiriana, a política, a teoria e a prática do que-fazer na educação, no espaço escolar e nas ações que acontecem fora desse espaço, numa perspectiva críticotransformadora”.

De acordo com esta dimensão do currículo, optou-se por partilhar a visão da escola do colonizado exposta por Albert Menni, um intelectual nascido na Tunísia e com importantes obras que discutem o colonialismo. Este autor foi citado por Freire em seus 
escritos, especialmente em Pedagogia do oprimido, em um conceito que, possivelmente, o iluminou para expor a aderência do oprimido ao opressor ${ }^{1}$.

Para Memmi (1977), a escola do colonizado não transmite ao povo sua própria herança. As tradições, aquisições, hábitos, conquistas, fatos e gestos das gerações precedentes do estudante colonizado serão inferiorizados e descartados e este estudante não se apropriará da memória do seu povo, pois a história que lhe é contada não é a sua.

Este conceito é aplicável ao currículo das escolas voltadas para as classes populares de São Paulo e mais especificamente da zona leste da cidade, já que, nessas escolas, valoriza-se a cultura erudita, repreendem-se os dialetos dos estudantes, criticam-se suas preferências musicais e seus gestos. Além disso, a história do povo preto, do povo nordestino, das mulheres, é apresentada de modo enviesado, associada à escravidão, ao analfabetismo, à seca e à exclusão. Essas escolas estabelecem uma dualidade, reforçam a negação e, no lugar de preparar o estudante para assumir-se totalmente, com uma postura crítica, forma um estudante que ambiciona ser como os dominantes, que deseja igualarse à elite, ainda que seja por meios não lícitos.

\section{ANÁLISE DAS ENTREVISTAS}

As entrevistas foram realizadas individualmente, fora do ambiente escolar. Todos(as) os(as) entrevistados(as) foram informados(as) sobre a finalidade deste estudo e assinaram o Termo de Consentimento Livre e Esclarecido (TCLE). Optou-se por entrevistar seis discentes da terceira série do ensino médio, que se autodeclarassem negros(as), sendo três da rede pública e três da rede privada.

Antes do início da análise das entrevistas, apresenta-se dados gerais dos(as) entrevistados(as) e, para homenagear a população negra, cada entrevistado(a) foi

\footnotetext{
${ }_{1}$ "[...] é interessante observar como Memmi, em uma excepcional análise da consciência colonizada, se refere à sua repulsa de colonizado ao colonizador mesclada, contudo, de apaixonada atração por ele" (FREIRE, 2005, p. 56).
} 
chamado pelo nome de homens e mulheres negros(as) que lutaram e lutam contra o racismo e a invisibilidade da população negra.

Quadro 1

Identificação discente

\begin{tabular}{|c|c|c|c|c|c|c|}
\hline Codinome & $\begin{array}{l}\text { Carolina de } \\
\text { Jesus }\end{array}$ & Pixinguinha & Dandara & $\begin{array}{l}\text { Emanoel } \\
\text { Araújo }\end{array}$ & $\begin{array}{l}\text { Milton } \\
\text { Santos }\end{array}$ & $\begin{array}{l}\text { Solano } \\
\text { Trindade }\end{array}$ \\
\hline Data & $23 / 11 / 2016$ & $16 / 11 / 2016$ & $19 / 11 / 2016$ & $18 / 11 / 2016$ & $19 / 11 / 2016$ & $22 / 11 / 2016$ \\
\hline Gênero & Feminino & Masculino & Feminino & Masculino & Masculino & Masculino \\
\hline Estado civil & Solteira & Separado & Solteira & Solteiro & Solteiro & Solteiro \\
\hline $\begin{array}{l}\text { Cursou } \\
\text { Ensino Médio }\end{array}$ & $\begin{array}{l}\text { (X) } \\
\text { pública ( } \\
\text { ) privada ( } \\
\text { ) as duas }\end{array}$ & $\begin{array}{l}(\mathrm{X}) \text { pública } \\
(\quad) \\
\text { privada ( ) } \\
\text { as duas }\end{array}$ & $\begin{array}{l}\text { (X) } \\
\text { pública ( } \\
\text { ) privada ( } \\
\text { ) as duas }\end{array}$ & $\begin{array}{l}\text { ( ) } \\
\text { pública (X } \\
\text { ) privada ( } \\
\text { ) as duas }\end{array}$ & $\begin{array}{l}\text { ( ) pública } \\
\text { (X) } \\
\text { privada ( ) } \\
\text { as duas }\end{array}$ & $\begin{array}{l}\text { ( ) pública } \\
(\mathrm{X}) \\
\text { privada ( ) } \\
\text { as duas }\end{array}$ \\
\hline Horário & Diurno & Noturno & Vespertino & Diurno & Vespertino & Diurno \\
\hline Idade & 17 anos & 30 anos & 17 anos & 17 anos & 17 anos & 16 anos \\
\hline $\begin{array}{l}\text { Como você se } \\
\text { considera }\end{array}$ & $\begin{array}{l}\text { Preta (X ) } \\
\text { Branca ( } \\
\text { ) Parda ( } \\
\text { ) Indígena } \\
\text { ( ) } \\
\text { Amarela ( } \\
\text { ) }\end{array}$ & $\begin{array}{l}\text { Preto ( ) } \\
\text { Branco ( ) } \\
\text { Pardo ( X } \\
\text { ) Indígena } \\
(\quad) \\
\text { Amarelo ( } \\
\text { ) }\end{array}$ & $\begin{array}{l}\text { Preta (X ) } \\
\text { Branca ( } \\
\text { ) Parda ( } \\
\text { ) Indígena } \\
\text { ( ) } \\
\text { Amarela ( } \\
\text { ) }\end{array}$ & $\begin{array}{l}\text { Preto (X ) } \\
\text { Branco ( } \\
\text { ) Pardo ( X } \\
\text { ) Indígena } \\
\text { ( ) } \\
\text { Amarelo ( } \\
\text { ) }\end{array}$ & $\begin{array}{l}\text { Preto (X ) } \\
\text { Branco ( ) } \\
\text { Pardo ( X } \\
\text { ) Indígena } \\
\text { ( ) } \\
\text { Amarelo ( } \\
\text { ) }\end{array}$ & $\begin{array}{l}\text { Preto (X ) } \\
\text { Branco ( ) } \\
\text { Pardo ( ) } \\
\text { Indígena ( } \\
\text { ) Amarelo ( } \\
\text { ) }\end{array}$ \\
\hline $\begin{array}{l}\text { Qual a sua } \\
\text { denominação } \\
\text { religiosa? }\end{array}$ & Cristã & Não tem & Espírita & Cristão & Evangélico & Católico \\
\hline $\begin{array}{l}\text { Participa de } \\
\text { algum } \\
\text { movimento } \\
\text { social? }\end{array}$ & $\begin{array}{l}\text { Sim, na } \\
\text { igreja. }\end{array}$ & Não. & $\begin{array}{l}\text { Feminista. } \\
\text { Vaca } \\
\text { Profana }\end{array}$ & Sim. & $\begin{array}{l}\text { Às vezes, } \\
\text { com a mãe } \\
\text { (que é } \\
\text { educadora) }\end{array}$ & Não \\
\hline
\end{tabular}

Fonte: autora, 2020

Os tópicos abordados nas entrevistas fazem referência a aplicação da Lei n. ${ }^{0}$ 10.639/o3 no currículo de História, com o objetivo principal de explicitar as percepções dos discentes do Ensino Médio a respeito da Lei. Procurando entender se o material didático, as práticas docentes, o currículo real e oculto, resgatam a contribuição do povo negro nas áreas social, econômica e política pertinente à História do Brasil. Bem como, se houve mudanças nos conteúdos curriculares, propiciando o estudo da História da África e dos Africanos, da luta dos negros no Brasil, da cultura negra brasileira e do negro na formação da sociedade nacional. 
Como técnica de análise, optou-se por realizar a análise de conteúdo que, de acordo com Bardin (2011), é um conjunto de técnicas de análises das comunicações que utiliza procedimentos sistemáticos e objetivos de descrição do conteúdo da mensagem. Tem por objetivo a inferência do conteúdo, recorrendo a indicadores quantitativos ou não, sendo que o objeto de análise é a fala, o aspecto individual da linguagem.

Para Fanon (2008, p. 33), “[...] falar é estar em condições de empregar certa sintaxe, possuir a morfologia de tal ou qual língua, é, sobretudo assumir uma cultura, suportar o peso de uma civilização”

E foi por meio da fala dos discentes do ensino médio, que são atores nesta pesquisa, que se buscou desvelar o mundo que a linguagem desses protagonistas descreve e analisa.

Tendo como princípio a visão de currículo mencionada, oito questões foram elaboradas a respeito do tema. A primeira refere-se à opinião dos estudantes no que diz respeito ao domínio, por parte dos docentes, de conteúdos comprometidos com a educação de negros e não negros e se estes docentes são capazes de corrigir posturas, atitudes, palavras que impliquem desrespeito e discriminação.

Para Carolina, na sua escola, os professores não têm domínio dos conteúdos comprometidos com educação de negros e não negros para combater a discriminação, pois em uma discussão com os alunos, apesar de o professor ser a favor das cotas para negros nas universidades, não teve argumentos para justificar sua posição.

Pixinguinha, que é da mesma escola, acredita que somente uma minoria dos professores está preparada, uma vez que já presenciou situações de discriminação na sala de aula com o professor presente e ele não interviu. Explica, também, que há professores negros que veem essa situação (de racismo) e não intervêm.

Dandara acha que os professores de ciências humanas são mais bem preparados do que os de exatas.

Para Emanoel, os professores negros são mais bem preparados; na verdade, ele acha que a professora é "encucada”, por corrigir o aluno por chamar o lápis rosa de cor da 
pele. Milton Santos também acha que a professora negra tratou melhor a questão. E Solano informa que os professores de geografia, história e português têm melhor domínio.

Percebe-se que há uma divisão entre a opinião dos entrevistados. Na escola pública, dois afirmam que os professores não estão preparados e um crê que apenas uma minoria o está. Na escola privada, dois concordam que os professores negros estão mais bem formados e que os professores da área de humanas lidam melhor com esses conteúdos.

Desse modo, os estudantes instigaram uma reflexão sobre formação docente e o porquê de os professores negros, em sua maioria, combaterem mais veementemente o preconceito e opressão.

Freire, na obra Pedagogia da autonomia (2000), retoma a questão da formação docente como prática educativo-progressiva e discute a inconclusão do ser humano, explicando que os educadores devem assumir a responsabilidade ética no exercício da docência, com reflexão crítica sobre esta prática, que não é de transferir conhecimentos, mas de produzir coletivamente o novo conhecimento.

Supõe-se que os professores das diferentes disciplinas têm consciência da inconclusão do ser humano, mas os estudantes esperam uma postura mais ativa dos professores da área de ciências sociais, uma vez que, tradicionalmente, o diálogo é uma constante nessas aulas, favorecendo discussões sobre discriminação, preconceito e outros temas da atualidade.

Retomando o segundo ponto, professores negros são mais engajados, entende-se que, por esses professores terem sido vítimas do racismo e da opressão, desencadeou-selhes a luta por ser mais e, hoje, esses docentes são protagonistas da transformação da realidade opressora.

O tema subsequente diz respeito à discussão dos temas relacionados à história e cultura dos negros no Brasil.

Referentemente a essa questão, os três entrevistados da escola pública informaram que a história dos negros foi retratada na época da escravização, associada à tortura e ao trabalho forçado. 
Pixinguinha disse que também houve uma discussão sobre religiões de matriz africana, com associação ao diabo.

Milton Santos informou que foram trabalhadas a escravidão e a resistência de Palmares.

Emanoel expôs que a professora tinha certo cuidado para falar sobre os negros, como se ficasse constrangida pelo fato de, em uma sala de 20 alunos, somente dois serem negros. Solano disse que o professor pedia para ele contar a história da sua família, pois sabia que seu bisavô fora escravizado; também narrou que a professora de geografia disse que havia racismo na Alemanha.

De acordo com Rodney (1982, p. 286), "En todo tipo de sociedad la educación es esencial para la preservación de la vida de sus miembros y el mantenimiento de la estructura social”. Certamente essa educação não se resume à educação formal e escolar, contemplando a educação adquirida no seio da família e relacionada ao sistema produtivo social. Rodney explica que, antes do período colonial, uma criança da Rodésia, de seis anos de idade, sabia nomear sessenta espécies de árvores, mas não sabia nada sobre flores ornamentais, pois o conhecimento das espécies de árvores era uma necessidade imposta pelo ambiente.

O autor prossegue explicando que os colonizadores não introduziram a educação em África. Muito antes da chegada dos europeus, já havia escolas de nível básico e superior, com universidades no Egito, Marrocos, Mali etc. Entretanto, os colonizadores introduziram instituições formais com o propósito de treinar africanos para os baixos cargos da administração e para fornecer mão de obra para as firmas capitalistas privadas. Esse tipo de educação não estava pautado nas condições concretas da sociedade africana e não era destinado a promover nos jovens o orgulho e a confiança de pertencer àquela sociedade, mas que “[...] procuró inculcar una actitud de respeto o deferencia frente a todo lo que fuera europeo y capitalista" (id., ib., p. 289).

A exemplo da educação instituída no continente africano pelos europeus, o currículo real das escolas pesquisadas não está pautado nas condições concretas dos 
estudantes negros(as); não promove a assunção e o orgulho de seu povo, que continua sendo retratado como escravizado. E mais: esse currículo continua promovendo o branqueamento das mentes colonizadas, associando o(a) negro(a) à favela e ao culto de demônios.

Como os relatos dos entrevistados revelaram, apenas a professora de Milton Santos, que é negra, conseguiu que os estudantes internalizassem a resistência negra, a partir do estudo do Quilombo dos Palmares. É sabido que o conteúdo do currículo oficial contempla a abolição e presume-se que os movimentos de resistência negra serão discutidos e haverá empoderamento dos estudantes negros(as), que conhecerão a história de homens, mulheres e comunidades inteiras, que foram guerreiras, não aceitaram a opressão e defenderam seus ideais com a vida. Contudo, o que se observa é que o currículo real não cumpre esse papel, talvez, por não abordar os temas ou, se o faz, não é capaz de promover a tomada de consciência dos entrevistados.

O questionamento aos(às) entrevistados(as) subsequente é se os estudantes sabiam em quais revoluções os negros participaram ao longo da história do Brasil.

Carolina e Emanoel não têm nenhuma memória sobre negros como participantes e/ou protagonistas nos processos revolucionários. Dandara e Solano só lembram-se do Mandela na África do Sul; no Brasil, não têm recordações sobre a participação de negros em lutas de resistência. Apenas Pixinguinha lembrou-se da Revolta da Chibata e Milton Santos, de Zumbi dos Palmares.

Ouvir tais respostas depois de mais de uma década da promulgação da lei que instituiu o estudo de história e cultura africana e afro-brasileira é, no mínimo, desolador e ratifica que o currículo real ainda é colonizado e racista.

Como elucidou Memmi, a herança de um povo é transmitida pela educação e, caso se interrogue ao colonizado "Quais são seus heróis populares? Seus grandes líderes populares? Seus sábios? Mal pode dar-nos alguns nomes. [...] o colonizado parece condenado a perder progressivamente a memória” (MEMMI, 1977, p. 94). A escola continua a lhe incutir a memória de um povo que não é o seu. 
Nesta parte da análise, procurar-se-á responder à questão se durante o Ensino Médio, as aulas de história colaboraram para resgatar a contribuição do povo negro nas áreas social, econômica e política no Brasil? Em quais momentos? Ou, por que não?

Carolina, Pixinguinha e Dandara informaram que não, pois o negro é representado apenas no período escravocrata. Contudo não há ênfase quanto ao papel da população negra no desenvolvimento da economia, na acumulação de capital etc. Pixinguinha se referiu a negros influentes no esporte e na música.

$\mathrm{Na}$ escola particular, o assunto é mais abordado. Emanoel disse que houve um ano em que trabalharam consciência negra de forma interdisciplinar.

Milton Santos também falou que sim, mas não se lembrava de detalhes.

Solano entende que, quando os professores explicam como os negros sofreram no passado, possibilitam entender que, no presente, o negro é um herói e "tem a mesma igualdade branca".

O não reconhecimento, por parte da escola, do protagonismo da população negra na área econômica é de fato curioso, uma vez que no, Brasil, praticou-se quatro séculos de modo de produção escravocrata, tendo essa população como produtora de praticamente toda a riqueza do país, atuando na agricultura, na pecuária, na mineração, no comércio e em tantas outras áreas econômicas. Além disso, os estudantes passam muitos anos estudando sobre o rei de Portugal, as intrigas entre Portugal e Espanha, as fofocas de alcova, entre outras histórias que pouco significam para os brasileiros, e, em contrapartida, praticamente nada é estudado e discutido sobre José do Patrocínio, Abdias do Nascimento, André Rebouças, Benedita da Silva, Dom Silvério Gomes Pimenta, Emanoel Araújo, Gilberto Gil, Manuel Querino, Paulo Paim e tantos outros negros e negras que participaram ativamente na vida política e cultural do Brasil.

A pergunta subsequente da pesquisa teve como objetivo saber se os entrevistados acreditavam que estudar história e cultura do(a) negro(a) no Brasil contribui para o reconhecimento e o orgulho do(a) estudante negro(a). 
Todos os entrevistados responderam que sim, estudar a história e cultura do povo negro contribuiria para assunção da própria identidade desses estudantes.

Para Carolina, estudar sobre os heróis negros traria orgulho.

Pixinguinha acredita que, se os estudantes souberem que houve negros importantes, vão pensar que também podem realizar grandes feitos. No entanto, Pixinguinha continua com o discurso de que o negro se vitimiza.

Dandara tem ciência que "se o negro não tivesse feito tanto coisa lá atrás, o Brasil não seria o que é hoje" e o reconhecimento da importância do povo negro "seria muita coisa".

Emanoel acredita que se mostrar que "outros negros vieram de tão de baixo e estão crescendo, daria um ânimo. Mostra que só depende dele mesmo".

De acordo com Milton Santos, mostrar que negros chegaram a níveis mais altos seria positivo.

Para Solano, ele representa a nova era e saber sobre a luta dos antepassados é um estímulo para continuar lutando.

Munanga e Nilma Gomes (2016, p. 20) afirmam que "as contribuições dos africanos trazidos para o Brasil, de quem descendem os brasileiros de hoje, são de três ordens: econômica, demográfica e cultural”. Os autores prosseguem narrando que os negros serviram como força de trabalho e sob a base econômica do país está o trabalho forçado do negro escravizado. No plano demográfico, os africanos ajudaram a povoar o país, sendo que, em 1830, os negros eram 63\% da população total. No plano cultural, dentre as contribuições dos africanos, destacam-se a língua, a religiosidade, a arte, a dança, a música, a arquitetura etc.

Considerando os conhecimentos disponíveis sobre a contribuição do povo negro ao Brasil e sabendo-se que, de acordo com o IBGE (2014), ele representa 53,6\% da população brasileira, por que o currículo das escolas públicas e privadas dedica um tempo e espaço ínfimo para tratar de suas contribuições para o País? 
Se os estudantes não sabem quem foram os grandes revolucionários negros; não conhecem a luta das mulheres de terreiro que, numa sociedade machista e classista, conservaram a tradição e tornaram-se mulheres de destaque; se os alunos não tem ciência que Juliano Moreira formou-se em medicina aos 19 anos de idade, tendo sido médico do escritor Lima Barreto que, por sua vez, foi contemporâneo de Machado de Assis, que era presidente da Academia de Letras; como esses jovens poderão assumir sua identidade e ter orgulho de ser negro? É preciso contar a história dos oprimidos; não retratá-los apenas como os "esfarrapados da terra", mas também como homens e mulheres "fazedores de história”.

A questão subsequente solicitou aos entrevistados que fossem informadas quais as principais ideias vinculadas à população negra na escola.

Para os três estudantes da escola pública, as principais ideias são: negros assassinados, pobreza, conotação pejorativa.

Os estudantes periféricos veem reproduzida, na escola, a realidade dos seus bairros: negros assassinados, miseráveis, seduzidos pelo crime e praticando o mal, como Pixinguinha dissera em outra pergunta da entrevista: religião de matriz africana associada ao demônio.

Para esses estudantes, parece ser mais difícil perceber mudanças significativas no currículo, possivelmente porque essas mudanças não ocorreram e se vierem a ocorrer precisarão ser pautadas em uma educação emancipadora, pois, apesar da inclusão, no currículo oficial, da história e cultura afro-brasileira, existem outras práticas que anulam as potencialidades transformadoras desse componente curricular.

Na escola privada, percebe-se que existe uma maior apropriação por parte dos estudantes dos componentes história e cultura afro, mas ainda persiste uma visão equivocada que reproduz a ideologia da democracia racial. Afinal, Solano afirmou que hoje existem mais negros nas escolas particulares. Sim, em uma sala com 25 estudantes, 3 são negros. 
No momento subsequente interrogou-se se existe projeto na escola que valoriza a história e a cultura afro-brasileira.

Pixinguinha, Dandara e Milton Santos informaram que não.

Carolina informou que houve um projeto sobre religião.

Emanoel e Solano informaram que houve um ano em que trabalharam consciência negra e direitos humanos de forma interdisciplinar.

A constatação de que, justamente na escola pública, onde se encontra a maioria da população negra, são poucos os projetos que contemplam a diversidade étnica. Ressaltase a importância da democratização da escola pública para a socialização dos saberes populares, tomando a linguagem popular como caminho da invenção da cidadania (FREIRE, 2009).

Aproximando-se do término da entrevista perguntou-se: Você acredita que as aulas de História, os livros didáticos e a própria escola ainda têm um viés (tendência) racista ou antirracista? Por quê?

Carolina e Dandara concordam que a escola tem um viés mais racista, devido ao enfoque na escravidão e por não dar "espaço ao negro".

Para Pixingiunha, Milton Santos e Solano, a escola é mais antirracista.

Finalmente, Emanoel acredita que "a escola pública deve ser mais racista. A particular (pausa) não teve nenhum caso de racismo, exceto aquele da professora”.

Em outro item deste artigo discutiu-se o que é racismo. Por isso, não se retornará, aqui, às conceituações. Entretanto, é relevante abordar, agora, o antirracismo.

Para Guimarães (2009, p. 228), o antirracismo deve agir em três frentes:

a) recuperação da autoestima negra, por meio das modificações de valores estéticos[...];

b) combate à discriminação racial, por meio da universalização da garantia dos direitos e das liberdades individuais;

c) combate às desigualdades raciais, por meio de políticas públicas que estabeleçam, a curto e médio prazo, um maior equilíbrio de riqueza, prestígio social e poder entre brancos e negros. 
Para que se obtenha sucesso nessas frentes é necessário que ocorra a mobilização da população negra, o que acontece de forma efetiva desde o período escravocrata. No entanto, se até o século XIX, as reivindicações estavam pautadas na liberdade do sistema escravocrata, a partir de então, as reivindicações são pelo efetivo gozo de direitos civis e sociais, resultando em um movimento antirracista. Para Guimarães (2009, p. 111), “[...] um racismo sem correspondente antirracismo corresponderia à eliminação física ou cultural do grupo racializado". A luta antirracista reivindica efetivação de ações afirmativas, que não se resumem ao acesso ao ensino superior, pois "[...] chamamos de ações afirmativas toda e qualquer política que tem por objetivo promover o acesso e permanência à educação, ao emprego e aos serviços sociais em geral de membros de grupos estigmatizados e sujeitos a preconceitos e discriminações”.

Definir o viés antirracista de uma escola não é uma tarefa simples, mas a presente pesquisa entende que uma escola antirracista caracteriza-se por:

a) incluir histórias infantis e juvenis em seu currículo, apresentando lendas e narrativas que contemplem diferentes maneiras de explicar o mundo e as relações sociais;

b) desenvolver projetos que valorizem protagonistas negros e negras nas áreas da educação, da medicina, do direito, da política, dos movimentos sociais e campos valorizados socialmente, não reforçando o estereótipo que negro(a) só é bom pra dançar e jogar bola;

c) adotar a promoção da igualdade como conteúdo permanente dos currículos;

d) valorizar a ancestralidade e a oralidade;

e) trabalhar para recuperar a identidade negra de seus estudantes, o que, de acordo com Gomes (2005), é uma construção social, histórica, cultural e plural;

f) lutar pela superação do mito da igualdade racial.

Os entrevistados não têm ciência da discussão realizada sobre racismo e antirracismo, mas em suas percepções, têm-se duas meninas negras que se sentem ignoradas, humilhadas e enxergam a escola e seus conteúdos como racistas.

Na percepção de Pixinguinha, a escola é antirracista. 
Os garotos da escola privada têm a percepção de que sua escola é antirracista e, pelos relatos, é possível inferir que as questões relacionadas à história e cultura afrobrasileira estão mais presentes no currículo da escola particular do que na escola pública. Porém, se se considerar as características e frentes de atuação da luta antirracista, é possível deduzir que a escola privada ainda apresenta ambiguidades.

Como a entrevista aqui relatada foi semiestruturada, reservou-se a última questão para que os estudantes pudessem falar livremente.

Carolina retoma o discurso de que as aulas reforçam apenas o período escravocrata e acrescenta que o preconceito racial tem resultado em morte, não só nas mãos dos policiais, mas as vítimas de racismo são torturadas mentalmente e às vezes tiram a própria vida. A estudante relatou que passou por um período de depressão profunda ocasionada pelo racismo e pensou em se suicidar. Essa revelação emocionou a pesquisadora e possibilitou refletir sobre o motivo da desolação da Carolina, o porquê de a estudante insistir em enfatizar a escravidão. Essa garota foi humilhada por ser negra e sente que lhe foi arrancada uma adolescência feliz em função de sua origem étnica.

Pixinguinha acredita que a mídia, a escola e outras instituições devem mostrar que a “cor da pele é só um detalhe” que não se deve julgar o outro pela cor. E defende que não se precisa julgar aquele que tem a pele dos escravizadores. Esse é o entrevistado mais velho, estudou no noturno trabalhando durante o dia. Afirma ser negro, mas critica o vitimismo do negro e prega que todos são iguais e não há motivo para cobrar nada dos brancos. Frente ao posicionamento do entrevistado, pode-se inferir que trata-se de um rapaz com a mente branqueada que julga ser seus os valores do outro.

Dandara faz um apelo para que o negro seja visto como membro integrante da sociedade, não continue a ser invisibilizado. Esta garota tem a ira justa; enxerga e combate o racismo e, de forma firme, exige o que é dela por direito.

Para Emanoel, a realidade ainda vai demorar muito para mudar; o racismo vai perdurar entre a polícia e nas próprias comunidades. Por fim, tem uma esperança que "se cada pessoa acredita que pode fazer o bem com relação ao racismo, não ter mais 
discriminação e falar isso para o próximo, estar incentivando, isso muda". Emanoel é muito perspicaz, disse ter sido das comunidades e hoje tem acesso a uma vida mais confortável, valoriza os bens materiais e acredita que o negro pode crescer sozinho; entretanto, ao longo da entrevista, em vários momentos, descreve casos de racismo, que ocorreram independentemente da sua condição social. Parece que o estudante não havia parado para refletir sobre o racismo até então, mas a própria entrevista transformou-se em um momento formativo que o levou à reflexão.

Milton Santos acha que o preconceito é resultado de inveja e se alguém o ofende é porque "você tem algo que o outro deseja". Milton Santos é um menino muito reservado. A mãe informou que o transferiu de escola, pois ele era perseguido na anterior, mas essa dor deve envergonhá-lo, de modo que, em sua entrevista, ele não olhava a pesquisadora nos olhos e não demonstrava alegria ou raiva diante das questões, apresentando apatia.

Solano diz que sua família tem orgulho de ser negra. Trata-se de um garoto meigo, solidário e, por vezes, ingênuo; por ser de uma família de classe média, estruturada e que o protege, possivelmente ele ainda não tem consciência da perversidade do racismo.

Considerando as respostas dos e das discentes entrevistados(a) é possível conjecturar que, apesar de quase duas décadas desde a promulgação da Lei n. ${ }^{0}$ 10.639/o3, sua aplicação ainda não é efetiva, os conteúdos curriculares obrigatórios e propostos na Lei c não foram incorporados no currículo de História e menos ainda de forma interdisciplinar na escola. Deste modo, acredita-se que existe um longo caminho a percorrer, pautado na formação docente (inicial e continuada), na luta antirracista e no processo de conscientização para que o cumprimento da Lei 10.639/o3 e a superação do viés racista no sistema de ensino brasileiro, seja efetivado. 


\section{CONSIDERAÇÕES FINAIS}

A presente pesquisa buscou desvelar o olhar escravocrata e colonialista do currículo de História, tendo como objeto a visão dos(as) discentes do Ensino Médio sobre a aplicação da Lei n. ${ }^{0}$ 10.639/o3 no referido currículo.

Para tentar responder a questões como a percepção do racismo por parte dos discentes, como o negro é visto na escola etc., seis discentes autodeclarados(as) negros(as), foram entrevistados(as). As questões da pesquisa indagam sobre a representação da população negra no currículo de História, possibilitando avaliar se os conteúdos da Lei citada, estão sendo cumpridos.

Todos os estudantes concordaram que estudar a História e Cultura da população negra seria um fator positivo para assunção da identidade negra e do orgulho de ser negro. Contudo, ainda estuda-se muito pouco sobre o tema e, ao abordar as personagens negras, suas origens não são reveladas, como ocorre com Machado de Assis, Aleijadinho, os irmãos Rebouças e tantos outros.

Relativamente ao racismo e o currículo, apenas Pixinguinha e Solano não percebem o racismo ocorrendo no momento presente. Carolina, Dandara e Emanoel confirmaram que já foram vítimas de racismo; Milton disse que não, só quando ele sai com o primo "é que lhe xingam de macaco". Pixinguinha tem dificuldade de reconhecer o racismo e, inclusive, culpa os negros de se posicionarem no lugar de vítima.

As duas meninas foram vítimas de racismo na escola: Carolina entrou em depressão e chegou a tentar o suicídio. Dandara foi acusada de ladra e, depois que o episódio foi esclarecido, o diretor da escola disse que ela estava inventando "essa história de racismo". Emanoel disse que procura andar arrumado, pois a polícia sempre o aborda na rua. Solano disse que nunca foi vítima de racismo, mas já presenciou um menino negro sendo agredido na escola e mesmo sem conhecer o garoto, Solano correu em seu auxílio.

Por fim, quando questionados quais as principais ideias vinculadas à população negra na escola, os estudantes da escola pública destacaram as seguintes: "negros 
assassinados", "pobreza” e outros termos pejorativos. Os meninos da escola privada citaram Machado de Assis, a luta do povo negro e a inclusão de estudantes negros na escola.

As vozes dos estudantes demonstraram que não houve mudança significativa na abordagem da população negra na escola. A história do negro continua associada ao período escravocrata, sem alusão à inércia da elite branca que acumulou capital a partir da exploração do conhecimento e força de trabalho da população negra.

As duas meninas da escola pública, percebem e sentem o racismo em sua vivência diária; em contrapartida, Pixinguinha, apesar de negro e periférico, tem a mente branqueada e não consegue perceber que também é vítima de preconceito e até mesmo discriminação racial. Emanoel, apesar de ser de classe média, também é vítima do racismo, principalmente por parte dos policiais, mas não enxerga o racismo na escola. Solano e Milton Santos, também não. Os estudantes da escola pública informaram que as ideias associadas aos negros na escola são sempre acompanhadas de assassinato e pobreza.

Os resultados apontam que, na escola pública, houve poucas mudanças com relação à abordagem do negro na história. O currículo de história, implícito e explícito, ainda é tradicional e o negro continua associado ao atraso, ao crime e à pobreza. São poucos os projetos que buscam a valorização da população negra na história, na política, na cultura e na sociedade do Brasil e, apesar de os estudantes da escola pública perceberem melhor o racismo, essa percepção é decorrente de outros componentes e, não, da abordagem crítica do racismo e da história e cultura do povo negro na instituição escolar.

$\mathrm{Na}$ escola particular, o conteúdo da referida norma é abordado com maior frequência, mas os procedimentos dos docentes, o material didático e o currículo oculto não são propícios para assunção da identidade dos poucos estudantes negros que têm acesso a uma escola privada, uma vez que não existe uma discussão sobre as causas do racismo, da manutenção do status quo e os estudantes apresentam posições ambíguas, 
por vezes concordando que o racismo existe e a escola pouco contribui para superá-lo, por outras, afirmando que a escola é antirracista.

A partir desta pesquisa é possível deduzir que a promulgação de uma Lei não é suficiente para modificar as práticas racistas no currículo escolar e na sociedade, contudo, não se pode diminuir a relevância da Lei n. ${ }^{0}$ 10.639/03, uma vez que esta é uma conquista do povo negro e não negro progressista, sendo uma importante ferramenta de luta que propiciou ampliar o debate contra o mito da democracia racial. Ainda não é o ideal, será preciso muita mobilização na formação docente, nos movimentos sociais, sindicatos e instituições públicas e privadas para efetivação de todos os artigos dessa Lei, contudo, como o caminho se faz caminhando, continuaremos nesta jornada.

\section{Referências}

APPLE, Michael W. Ideologia e Currículo. Tradução de João M. Paraskeva. Porto, Portugal : Porto Editora, 1999.

BARDIN, Laurence. Análise de conteúdo. Tradução de Luís Antero Reto e Augusto Pinheiro. São Paulo: Edições 70, 2011.

BRASIL. Ministério da Justiça e Segurança Pública. População carcerária brasileira chega a mais de 622 mil detentos. Brasília, DF, 26 abr. 2016. Disponível em: http://www.justica.gov.br/noticias/populacao-carceraria-brasileira-chega-a-mais-de622-mil-detentos. Acesso em: 30 jun. 2016.

. Portal Brasil. Mercado ainda reflete preconceitos contra mulheres, pretos e pardos, revelam dados do IBGE. Brasília, DF, 29 jan. 2015. Disponível em: http://www.brasil.gov.br/economia-e-emprego/2015/o1/mercado-ainda-refletepreconceitos-contra-mulheres-pretos-e-pardos-revelam-dados-do-ibge. Acesso em: 30 jun. 2016.

. Lei n. ${ }^{\circ}$ 9.459, de 13 de maio de 1997: altera os arts. $1^{\circ}$ e 20 da Lei $n^{0} 7.716$, de 5 de janeiro de 1989, que define os crimes resultantes de preconceito de raça ou de cor, e acrescenta parágrafo ao art. 140 do Decreto-lei $n^{0}$ 2.848, de 7 de dezembro de 1940. Brasília, DF, 1997.

. Lei . $^{\circ} 10.639$ de og de janeiro de 2003: altera a Lei $\mathrm{n}^{\circ} 9.394$, de 20 de dezembro de 1996, que estabelece as diretrizes e bases da educação nacional, para incluir no currículo oficial da rede de ensino a obrigatoriedade da temática História e Cultura 
Afro-Brasileira, e dá outras providências. Brasília, DF, 2003. Disponível em: http://www.planalto.gov.br/ccivil_03/leis/2003/l10.639.htm. Acesso em: 24 jun. 2014.

.Lei . $^{\circ}$ 12.288, de 20 de julho de 2010: institui o Estatuto da Igualdade Racial; altera as Leis nos 7.716, de 5 de janeiro de 1989, 9.029, de 13 de abril de 1995, 7.347, de 24 de julho de 1985, e 10.778, de 24 de novembro de 2003. Brasília, DF, 2010. Disponível em: http://www.planalto.gov.br/ccivil_03/_ato20072010/2010/lei/l12288.htm. Acesso em: 24 jun. 2014.

. Ministério da Educação. Resolução $n^{\circ} 4$, de 13 de julho de 2010: define Diretrizes Curriculares Nacionais Gerais para a Educação Básica, DF, 2010.

CASHMORE, Ellis et al. Dicionário de relações étnicas e raciais. Tradução de Dinah Kleve. 2. ed. São Paulo: Selo Negro, 2000.

COORDENADORA DOS ASSUNTOS DA POPULAÇÃO NEGRA - CONE. Como reconhecer e como lidar com o racismo em suas diversas formas. São Paulo: Ibraphel, 2010.

DENEGRIR. In: DICIONÁRIO online de português. Disponível em: http://www.dicio.com.br/denegrir/. Acesso em: 22 jun. 2014.

DINIZ, Débora. A custódia e o tratamento psiquiátrico no Brasil: censo 2011. Brasília: Letras Livres: Editora Universidade de Brasília, 2013.

FANON, Frantz. Pele negra, máscaras brancas. Tradução de Renato da Silveira. Salvador, BA: EDUFBA, 2008.

FERREIRA, Aurélio. Mini Aurélio. 3. ed. Rio de Janeiro: Nova Fronteira, 1993.

FREIRE, Paulo. Pedagogia do Oprimido. São Paulo: Paz e Terra, 2005.

. Pedagogia da Autonomia: saberes necessários à prática educativa. 14. ed. São

Paulo: Paz e Terra, 2000.

. Educação como prática da liberdade. Rio de Janeiro: Paz e Terra, 2009.

GUIMARÃES, Antônio Sérgio A. Preconceito racial: modos, temas e tempos. São Paulo: Cortez, 2008.

. Racismo e antirracismo no Brasil. 3. ed. São Paulo: Ed. 34, 2009.

GOMES, Nilma Lino. Alguns termos e conceitos presentes no debate sobre relações raciais no Brasil: uma breve discussão. In: BRASIL. Ministério da Educação. Secretaria de educação continuada e alfabetização e diversidade. Educação Antirracista: caminhos abertos pela Lei federal no 10.639/o3. Brasília, DF, 2005. p. 39-62. 
LIBÂNEO, José Carlos; OLIVEIRA, João Ferreira de; MIRZA, Seabra Toschi. Educação escolar: políticas, estrutura e organização. São Paulo: Cortez, 2003.

LOPES, Nei. Dicionário escolar afro-brasileiro. São Paulo: Selo Negro, 2006/2015

LOPES, Nei. Enciclopédia brasileira da diáspora africana. 3. ed. São Paulo: Selo Negro, 2004.

MEMMI, Albert. Retrato do colonizado precedido pelo retrato do colonizador.

Tradução Roland Corbisier; Mariza Pinto Coelho. 3. ed. Rio de Janeiro: Paz e Terra, 1977.

MUNANGA, Kabengele; GOMES, Nilma Lino. O negro no Brasil de hoje. 2. ed. São Paulo: Global, 2016.

NOVAES, Fernando A. Portugal e Brasil na crise do antigo sistema colonial. São Paulo: Hucitec, 1979.

RODNEY, Walter. De cómo Europa subdesarrolló a África. México: Siglo veintiuno, 1982.

SAES, Décio. A formação do estado burguês (1888-1891). Rio de Janeiro: Paz e Terra, 1985 .

SAUL, Ana Maria. Currículo. In: STRECK, Danilo R; REDIN, Euclides; ZITKOSKI (Org.). Dicionário Paulo Freire. 2. ed. Belo Horizonte: Autêntica, 2010. p. 109-110.

SILVA, Tomaz Tadeu da. Documentos de identidade: uma introdução às teorias do currículo. Belo Horizonte: Autêntica, 1999.

. O Currículo como fetiche: a poética e a política do texto curricular. Belo Horizonte: Autêntica, 2001.

WAISELFISZ, Julio Jacob. Mapa da Violência 2014: jovens do Brasil. Rio de Janeiro: Flacso Brasil, 2014.

YOUNG, Michael. Teoria do currículo: o que é importante. Tradução Leda Beck. Cadernos de Pesquisa. v. 44, n. 151, p.190-202, jan.- mar. 2014.

\section{Sobre a autora:}

Neide Cristina da Silva: Graduada em História, Turismo e Pedagogia. Mestre em Educação. Doutora em Educação. Professor(a) na UniDrummond. Lider do grupo YlêEducare: educação e questões étnico-raciais. E-mail: neidesilva87@hotmail.com 